\title{
Lifetimes and Legacies: Mortality, Immortality, and the Needs of Aging and Dying Donors
}

Geoff Wexler and Linda Long

\begin{abstract}
A b s t r a ct
Archivists frequently collect papers from people who have had long and productive careers, but are challenged by aging, infirmity, and the end of life. Closely related is the archivist's work with caregivers, survivors, and heirs. Geoff Wexler explores the often complex legal, ethical, and interpersonal implications involved when confronting issues of aging, death, and the documentary legacies of the departed. Linda Long provides a case study that examines an archivist's relationship to a terminally ill artist, Tee Corinne. An annotated bibliography concludes the article.
\end{abstract}

Introduction: Archivists and the "Afterlife"

Aging, dying, and death are subjects imbued with such negative connotations that we often surround them with euphemism, metaphor, and plain avoidance. However, as archivists we must acknowledge that our profession is intimately bound up with these life events. Those of us responsible for acquiring collections often work with people at the end of their careers and the end of their liveswhether or not they are able to acknowledge these realities. In addition, archival work often involves those who are left behind-widows and widowers, lovers and partners, siblings, relatives, and friends, not to mention colleagues and loyal employees, executors, and lawyers. Archivists have a responsibility to all of these people-perhaps even a sacred responsibility, to preserve the records that remain.

(C) Geoff Wexler and Linda Long.

This article began as a session titled "Lifetimes and Legacies: Caring Approaches to the Elderly, the Infirm, and Their Survivors" at the Society of American Archivists' Annual Meeting in Chicago, presented 30 August 2007. Robin Rider and Steven Mandeville-Gamble also spoke at the session and some of their ideas are included in the present article, with grateful acknowledgment. 
L I F E T I M E S A N D L E G A C I E S : M O R T A L I T Y , I M M O R T A L I T Y ,



Archivists sometimes inhabit what historian Michael Lesy has called "the forbidden zone." In his 1989 book of that title, he examines the life and work of people who deal intimately with death on a daily basis, such as homicide detectives, morticians, kosher butchers, and soldiers. These individuals mediate between the living and the dead. Their routine jobs take them directly into that "forbidden zone," which human society handles with the utmost care, a zone surrounded with an intricate buffer of ritual, spirituality, medical science, even art and literature-not to mention simple avoidance and denial. "Those who deal with death," writes Lesy, "work at an intersection of opposites, tainted by the suffering and decay of the body, transfigured by the plight of the self and the destiny of the soul."1

To say that archivists have a sacred mission might be considered metaphysical when looked at from a purely secular perspective. But even when seen from the most mechanistic point of view, our jobs do involve such things as immortality, or afterlife, or even salvation in its most literal sense. If one chooses to define the soul as the very essence of the person-her or his thoughts, ideas, misconceptions, prejudices, delusions, aspirations—archivists are certainly in the business of saving souls. Through the preservation of people's letters and diaries and photographs and high school report cards; through the saving of the multifarious detritus people have accumulated throughout their physical existence, those who preserve records transform what the person once was into what she or he is now, to us, the living. As archivist James O'Toole says, archival records "are carriers of information that speak, from one person to another, across the barriers of time, distance, and experience."

Although many archivists deal with issues related to aging, death, and survivors, little in the archival literature relates to these issues. One archival manual states simply, "The donor may have an intense emotional reaction to the memorabilia of a spouse or parent and the field agent will need to exercise tact in meeting these feelings while getting his job done." ${ }^{3}$ Most of the literature focuses on the technicalities of donor relations, such as legal precautions, accurate recordkeeping, and appraisal of the materials on-site. ${ }^{4}$ Others consider the

\footnotetext{
${ }^{1}$ Michael Lesy, The Forbidden Zone (New York: Farrar, Straus and Giroux, 1987), 5. Be warned, this book contains some passages of a graphic and violent nature.

2 James M. O’Toole, Understanding Archives and Manuscripts (Chicago: Society of American Archivists, 1990), 69.

${ }^{3}$ Virginia R. Stewart, "A Primer on Manuscript Field Work," in A Modern Archives Reader, ed. Maygene F. Daniels and Timothy Walch (Washington, D.C.: National Archives and Records Service, 1984), 132.

${ }^{4}$ See, for example, Barbara J. Kaiser, "Problems with Donors of Contemporary Collections," American Archivist 32, no. 2 (1969), 103-7; James Gregory Bradsher, ed., Managing Archives and Archival Institutions (Chicago: University of Chicago Press, 1988), 80-82; and Ann Pederson, ed., Keeping Archives (Sydney: Australian Society of Archivists, 1987), 101-9. For the use of collection development policies to deflect unwanted donations see Cynthia K. Sauer, "Doing the Best We Can?: The Use of Collection Development Policies and Cooperative Collecting Activities at Manuscript Repositories," American Archivist 64 (Fall/Winter 2001), 324. For a case study in an effective approach to Vietnam veterans (many of whom were elderly) and their families, see Michael E. Stevens, "Voices from Vietnam: Building a Collection from a Controversial War," American Archivist 64 (Spring/Summer 2001): 115-20.
} 
psychology of interpersonal contacts but do not delve deeply into these admittedly emotional and sometimes spiritual concerns. ${ }^{5}$ This is not surprising given what must surely seem to most busy archivists as an area filled with problems better addressed by professionals in other realms, such as medicine, psychology, social work, and religion.

But even if most archival training cannot, in a practical sense, encompass the complexity of issues within this sensitive zone of life and death, as archivists we must have some understanding of these matters to fulfill our mission effectively. We take for granted that knowledge of a particular subject area is important to an archivist working with papers relating to that discipline-for instance, the history of science in relation to the papers of a physicist. ${ }^{6}$ Likewise, some general knowledge of the chemistry of paper is fundamental to preserving manuscript collections. It follows, then, that an understanding of aging, death, and survivorship is important to archivists when working with the elderly, the terminally ill, and those who survive them.

The literature on the subjects of aging, death, and survivorship is voluminous. The last three decades have seen an outpouring of popular books and articles dealing with them. ${ }^{7}$ Although it is beyond the scope of this article to analyze this literature thoroughly, a few significant selections may help orient the archivist.

Of particular note is the landmark 1969 work by physician Elisabeth KüblerRoss titled On Death and Dying. ${ }^{8}$ Although intended primarily for medical professionals, it is accessible and filled with insights applicable to anyone dealing with the terminally ill or dying. Its significance, for its time, lay in its emphasis on the needs of the dying person, rather than on the agendas of caretakers and attendants. ${ }^{9}$ Kübler-Ross delineates five stages of consciousness undergone by those who are diagnosed with a terminal illness. These are

- Denial and isolation

- Anger

- Bargaining

- Depression

- Acceptance

Not all patients pass through each phase, and often a person will end life without reaching acceptance. The author also suggests that survivors themselves

\footnotetext{
${ }^{5}$ See especially F. Gerald Ham, Selecting and Appraising Archives and Manuscripts (Chicago: Society of American Archivists, 1993), 40-43. Ham provides some very solid practical advice gleaned from long years of experience, although some may interpret this passage as cynical.

${ }^{6}$ O'Toole, Understanding Archives and Manuscripts, 43.

${ }^{7}$ Setting aside the vast sociological work stretching back to scholars such as Sigmund Freud and Emile Durkheim (and earlier), Lynne Ann DeSpelder and Albert Lee Strickland, Last Dance: Encountering Death and Dying (Palo Alto: Mayfield Publishing Company, 1983), 28-29.

${ }^{8}$ Elisabeth Kübler-Ross, On Death and Dying (New York: Scribner Classics, 1969, 1997).

${ }^{9}$ DeSpelder and Strickland, Last Dance, 29.
} 
L I F E T I M E S A N D L E G A C I E S : M O R T A L I T Y , I M M O R T A L I T Y ,

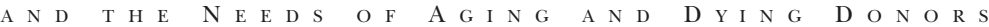

may pass through these phases too. ${ }^{10}$ Those dealing with the terminally ill must understand these phases and respond appropriately when confronted by donors in the midst of them.

In archival collecting, denial is often encountered when an elderly or ailing person is first contacted in regard to her or his papers. "Psychologically," writes archivist F. Gerald Ham, "some people react to a request for their records as they would to one asking them to arrange for their own funeral." ${ }^{11}$ For example, an elderly emeritus faculty member refused to move his extensive files from a large university office needed by his department for use by active professors. Repeated visits from the university archivist proved futile in changing the professor's mind. His life had been his work, and giving up his papers would be an admission that the end was near-which, in fact, it was. ${ }^{12}$ In these and other cases, the archivist should try to give the donor or the survivors as much time as needed, regardless of the repository's agenda. This may be difficult, given the needs of administrators. But the archivist can diplomatically assure her or his superiors that a delayed collection is better than no collection at all. In some cases, the archivist may choose to receive a small portion of the collection at first, thereby demonstrating to the institution that the acquisition process has at least begun.

Anger often manifests once the reality of impending loss or death has finally sunk in, and it may be directed at anyone or anything. It may be a sense of injustice or victimization, and even if the death was a natural one, survivors may also feel anger. Anger must run its course, even if it entails the isolation of the dying person or the mourner. ${ }^{13}$ I once stood by as a noted and respected composer, confined to a wheelchair in the last stages of a terminal illness, lashed out unmercifully at his devoted wife. "I must organize my papers now!" he yelled. ${ }^{14}$ And, as archivists, we must be emotionally prepared for anger directed at us. These situations can often test the strength of one's sense of professional objectivity but must be understood as part of the dying and the grieving process.

Bargaining can often be an attempt to postpone the inevitable or, in the case of a survivor, to somehow bring the deceased back, either corporeally or through the imagination. ${ }^{15}$ Often, personal papers play a role in this bargaining, and

${ }^{10}$ Kübler-Ross, On Death and Dying, 51, 63, 93, 97, 98, 123, 176, and passim. This "stage" conceptualization has, like all such ideas, come under intense criticism in recent years; see Thomas Attig, How We Grieve (New York and Oxford: Oxford University Press, 1996), 44-47.

${ }^{11}$ Ham, Selecting and Appraising Archives and Manuscripts, 43.

12 This example is drawn from the author's own experience as a university archivist; see also Margaret Cruikshank, Learning To Be Old: Gender, Culture and Aging (Lanham, Md.: Rowman and Littlefield, 2003), 45 .

${ }^{13}$ Elisabeth Kübler-Ross and David Kessler, On Grief and Grieving: Finding the Meaning of Grief through the Five Stages of Loss (New York, London, Toronto, Sydney: Scribner, 2005), 12-17.

${ }^{14}$ Again, this example is drawn from the author's own experience as a university archivist.

${ }^{15}$ Kübler-Ross, On Death and Dying, 95. 
many lengthy negotiations may result as a dying person bargains for more time to live, or a survivor balks at giving up the physical manifestations of the departed loved one. In some cases, donors or their survivors may insist upon a detailed examination of the collection on an item-by-item basis, emphasizing to the archivist the importance of the materials. As trying as this may be, the archivist must understand this process as a part of a delicate coming to terms with dying and death. ${ }^{16}$

Depression may result in a breakdown in communication with the repository, as the donor withdraws from any activity. The archivist must acknowledge the possibility that the donor is depressed and is not necessarily reconsidering the donation. Family members, friends, or associates of the donor might communicate about his or her depression. Here again, it is important to be available but not to overwhelm the donor with questions about the donation. Because depression may be long lasting, the archivist must practice patience and understanding.

When acceptance of death finally comes, a dying person often desires solitude or few visitors, and little news of the outside world. At the same time, the family may need more attention and help during this period. ${ }^{17}$ At this point, it is crucial for the archivist to be available for family and close friends. Either the dying person-or later the survivors—may make final plans for the disposition of papers during the period of acceptance.

Although Kübler-Ross's work has been both augmented and contested, her insights provide a good starting point for archivists. It is important, she says, to always be available to those left behind: “. . . let the relative talk, cry, or scream if necessary. Let them share and ventilate, but be available. . . . if we tolerate their anger, whether it is directed at us, at the deceased, or at God, we are helping them take a great step towards acceptance without guilt." 18

In a later work, Kübler-Ross and co-author David Kessler give greater detail about relating to survivors. They stress the importance of the survivor's storythe narrative he or she has created to understand the loss: "Telling the story helps to dissipate the pain. .. . You must get it out. Grief must be witnessed to be healed.... When someone is telling you their story over and over, they are trying to figure something out."19 The survivor also highlights the importance of the deceased person's personal affects; dealing with them is part of a ritual act that helps the survivor "accept the reality of the loss." "Letters have a special

\footnotetext{
${ }^{16}$ Diplomacy in these situations is an art learned through experience, of course. One technique is to assure the person that you will be available at a later time to continue with the examination of the collection, although your schedule requires you to leave now.

${ }^{17}$ Kübler-Ross, On Death and Dying, 128.

${ }^{18}$ Kübler-Ross, On Death and Dying, 186.

${ }^{19}$ Kübler-Ross and Kessler, On Grief and Grieving, 63, 66.
} 
L I F E T I M E S A N D L E G A C I E S : M O R T A L I T Y , I M M O R T A L I T Y ,

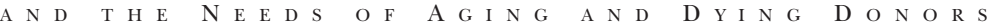

power in that they are tangible evidence that our loved one took the time and effort to sit and write on the very paper we hold in front of us. ... The proof of someone's presence exists in his or her handwriting. ${ }^{20}$ Thus, the archivist may play a most significant role in the grieving process itself, as illustrated by the following case of artist Tee Corinne. The papers of the deceased can form the core of the "story" that connects them to their survivors. ${ }^{21}$

The survivors of people who have committed suicide have special needs. To build a positive image of the suicide victim, the survivor especially needs reassurance from both family members and the community. ${ }^{22}$ The archivist can play a role here as a representative of the community's collective memory. Preserving the documentary legacy of the victim can serve both to validate that person's contributions to society and to assist the survivors in understanding the reasons and motivation for the suicide. Linda Long poignantly illustrates this when she discusses how she helped one of Tee Corinne's survivors come to terms with the artist's death. ${ }^{23}$

Even though secular archivists may feel uncomfortable thinking of this work as part of anything other than fulfilling professional responsibilities, we must understand that such work is also a component of a contemporary ritual. In much the same way that late-nineteenth-century portrait photography extended the rituals surrounding life's events—birth, graduation, marriage, recognition of achievements, death—collecting papers also marks important milestones in the life of an individual or corporate body. ${ }^{24}$ Retirement from a career, completion of significant work or a project, the centennial of an organization, the sale of a long-term business, the death of an individual—ritual often accompanies these events, including the preservation of records, papers, and artifacts. Like all rituals, which connect us to things larger and greater than ourselves, acquisition of papers and records connects the history of the individual or organization with the larger storehouse of recorded knowledge embodied in the repository. ${ }^{25}$ Archivists must understand this ritual nature of preserving records. Having been

${ }^{20}$ Kübler-Ross and Kessler, On Grief and Grieving, 136, 145.

21 "As caregivers, we can help the bereaved find new direction, purpose, and meaning in their life stories. We can help them to reconnect with their past, present, and future in meaningful ways" (Thomas Attig, How We Grieve, 160-61). "Eagerness to tell one's story signals a desire to live" (Margaret Cruikshank, Learning To Be Old: Gender, Culture, and Aging, 48).

${ }^{22}$ E. Betsy Ross, After Suicide: A Ray of Hope for Those Left Behind (Cambridge, Mass.: Perseus Publishing, 2001), 155.

${ }^{23}$ I am currently processing the papers of a gay man who committed suicide in the late 1990s. He was highly educated and an excellent writer. Although he published little, his diaries provide a brilliant insight into his life in New York City and Portland, Oregon. He died in relative obscurity, but thanks to the preservation of his papers, his work may someday be well known.

${ }^{24}$ Michael Lesy, Wisconsin Death Trip (New York: Pantheon Books, 1973), [xiii].

${ }^{25}$ Robert Kastenbaum, Our Way: The Final Passage through Life and Death (Berkeley and Los Angeles: University of California Press, 2004), 6. 
trained as keepers of information, we archivists should know that we are alsowhether we like it or not-keepers of sacred legacies. ${ }^{26}$

But even when death is still a dim shadow in the background-or, in T. S. Eliot's characterization, "the perpetual footman"-the elderly are constantly aware of its presence. Like the dying, the elderly may also pass through the five stages identified by Kübler-Ross. And understanding these and other aspects of aging is important for archivists who collect papers and records, since the aged are prominently represented among donors.

The literature on aging has also grown exponentially over the last few decades. ${ }^{27}$ The new literature in part reflects the rapid expansion of the world's elderly population in recent times, and it also reflects sharply declining fertility rates, especially in the United States. Life expectancy in the United States jumped from 47.3 years in 1900 to 75.5 in 1991, and it is predicted that, by 2050, it will be eighty-six years for men and ninety-two for women. ${ }^{28}$ With the aging of the "baby boomers," who have assumed greater social and economic power in our society, we may soon become what one author has called a "gerontocracy"a nation run by the elderly. ${ }^{29}$ This trend has obvious implications for those collecting personal papers. Archivists should expect to receive larger collections that may come to their repositories over longer and longer periods of time. ${ }^{30} \mathrm{In}$ addition, they will need a greater understanding of the aging process and the needs of elders. Above all, archivists must see the aged not as people no longer useful or vital, but people who have entered a stage in life where, as author Betty Friedan writes, "there are no prescribed role models to follow, no guideposts, no rigid rules or viable rewards." 31

Archivists should also seek to understand how the aging experience varies for people in diverse ethnic and racial communities, disparate economic situations,

\footnotetext{
${ }^{26}$ Those of us who work in old historical societies may understand this better than others. Most of these institutions were founded by the pioneer families of the region-people who saw the repositories more as halls of fame for the so-called founders of their communities, not as libraries filled with information for scholars; see, for example, Amanda Laugesen, "George Himes, F. G. Young, and the Early Years of the Oregon Historical Society,” Oregon Historical Quarterly 101 (Spring 2000): 21-24.

${ }^{27}$ Although a selected bibliography is provided at the end of this article, a more thorough list of works can be found in Terry Tirrito, Aging and the New Millennium: A Global View (Columbia: University of South Carolina Press, 2003); more extensive and specialized bibliographies can be found in James E. Birren et al., eds., Handbook of the Psychology of Aging (Amsterdam: Elsevier, 2007), and in Robert Binstock and Linda K. George, Handbook of Aging and the Social Sciences (Boston and London: AP Professional, 2005).

${ }^{28}$ Tirrito, Aging and the New Millennium, 11-13, 67-68; James H. Schulz, The Economics of Aging, $7^{\text {th }}$ ed. (Westport, Conn. and London: Auburn House, 2001), 305.

${ }^{29}$ Ken Dychtwald, Age Power: How the $21^{\text {st }}$ Century Will be Ruled by the New Old (New York: Jeremy P. Tarcher/Putnam, 1999), 235.

${ }^{30}$ The author's repository has been receiving yearly installments of a woman's diary for over twenty years. She is now in her midnineties and quite healthy, so more is expected.

${ }^{31}$ Betty Friedan, The Fountain of Age (New York: Simon and Schuster, 1993), 69.
} 
L I F E T I M E S A N D L E G A C I E S : M O R T A L I T Y , I M M O R T A L I T Y ,

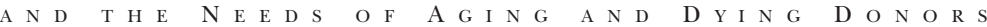

and differing locales. It is especially important to comprehend the dynamics of aging in an urban society, where family ties are often more tenuous, individual isolation is more widespread, and the segregation of elders from other age groups is more likely. ${ }^{32}$ One implication for archivists is that elders may tend to develop personal bonds with a repository's representative. Such bonds serve as a sense of connection not only to a larger world (the repository, the world of knowledge) but as a way of perpetuating the kind of personal legacy that, in older and more traditional societies, might have been passed on to succeeding family generations. For example, elders frequently confess, somewhat awkwardly, to archivists that their children or grandchildren do not want their collections of family papers or photographs. Likewise, archivists often receive calls from friends or neighbors in the process of helping single elderly people move from long-time homes to assisted care facilities. "We don't know what to do with all this stuff," they say, "there's nobody to give it to." ${ }^{\prime 3}$ As aging in an urban society is increasingly an isolating process, archivists and other professionals may often be called upon to serve as vital connections to an outside world. In working with elders, archivists can bring isolated and marginalized individuals into what Jeannette Bastian calls a "community of records"-communities "rooted not just in physical localities but in social groupings and networks that share culture or experiences, that is, social memory." ${ }^{34}$ As with the dying or the deceased, personal papers can validate an elder's contribution to society.

Archivists, then, can serve elders as agents of legacy and as part of what sociologist Harold L. Sheppard calls an "ethic to the future." ${ }^{35}$ Similarly, archivists often serve the dying and their survivors as guardians of a personal legacy. Such roles need not compromise professional standards or ethics, even if archivists develop personal bonds with those whose collections they are acquiring. "Professional standards," writes archivist Randall Jimerson, "need not prevent us from addressing moral, ethical, or political issues. A common fallacy is to equate objectivity with neutrality." ${ }^{36}$ If anything, a genuinely caring approach to elderly, dying, or grieving donors can only enhance an archivist's sense of professional responsibility.

\footnotetext{
${ }^{32}$ Vern L. Bengston, Patricia L. Kasschav, and Pauline K. Ragan, "The Impact of Social Structure on Aging Individuals," in Handbook of the Psychology of Aging, ed. James E. Birren and K. Warner Schaie (New York: Van Nostrand Reinhold Company, 1977), 322.

${ }^{33}$ Examples of this sort could fill a separate volume. The author received a valuable collection left behind in the basement of a downtown apartment house; the elderly owner had died alone, and neither his divorced wife nor his estranged son wanted the materials.

${ }^{34}$ Jeannette Bastian, Owning Memory: How a Caribbean Community Lost Its Archives and Found Its History (Westport, Conn.: Libraries Unlimited, 2003) as quoted in Elizabeth Yakel and Deborah A. Torres, "Genealogists as a 'Community of Records'," American Archivist 70 (Spring/Summer 2007), 97.

${ }^{35}$ Harold L. Sheppard, "Work and Retirement," in Handbook of Aging and the Social Sciences, ed. Robert H. Binstock and Ethel Shanas (New York: Van Nostrand Reinhold Company, 1976), 388.

${ }^{36}$ Randall C. Jimerson, “Archives for All: Professional Responsibility and Social Justice,” American Archivist 70 (Fall/Winter 2007): 272.
} 
The following narrative by Linda Long vividly illustrates such an approach. Her story of personal engagement in a delicate donor situation demonstrates some of the vital ways archivists can play an essential role in preserving the legacies of the departed.

Experience with a Dying Donor: The Case of Tee Corinne

Introduction

On 27 August 2006, artist, photographer, writer, and lesbian activist Tee Corinne ended her life under Oregon's Death with Dignity Act (at the time, Oregon was the only state that legally allowed terminally ill individuals to end their lives through physician-assisted suicide). Tee had been diagnosed with inoperable liver cancer just six months before, in March 2006, and after a series of treatments that would never cure her of cancer, she opted to end her life the way she had lived it: with openness and dignity. When the disease grew unbearable, she invited several close friends in the lesbian community in southern Oregon to witness her death. One Sunday morning, Tee lay in her bed, while two women held her hands, and eighteen more stood in her living room singing songs Tee had chosen. She wanted to die hearing women's voices singing in unison. Then Tee drank eight ounces of a liquid barbiturate and immediately fell asleep. Fifteen minutes later, she had stopped breathing.

My experiences with Tee, her death, and the acquisition of the remainder of her papers, while serving as a representative of the university that is the beneficiary of her estate and copyright, were also emotional and dramatic. Most of these experiences were new to me. Before Tee's death, I had never had to think about the wording of a will, and I had very little experience saying goodbye to dying donors. In fact, Tee was only the second; in a macabre and cruel coincidence, the first was Tee's partner of sixteen years, Beverly Brown.

This case study discusses the events surrounding Tee's death and her bequests to the University of Oregon. It focuses on three situations: my work with Tee prior to her death, particularly the wording in her will; my work with her executor after Tee's death; and my interactions with Tee's last lover.

Te e Corinne

Tee Corinne was born in 1943 in St. Petersburg, Florida. She was a southerner, living in Florida and North Carolina with her family until moving to New Orleans as a young woman. In 1968, she received an MFA from the Pratt Institute, and by the early 1970s, she began to experiment with sexual content in her art. The sexual imagery she found in the "great masters" motivated her 
L I F E T I M E S A N D L E G A C I E S : M O R T A L I T Y , I M M O R T A L I T Y ,

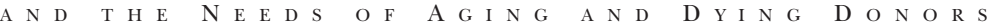

to begin experimenting in her own photographs and drawings. Starting safely with photographs of heterosexual couples kissing, she moved to drawing her own genitals because no other models were available. Tee was aware that she was an iconoclast. She loved the famous quote by Laurel Thatcher Ulrich, now a professor of history at Harvard University, "Well-behaved women rarely make history." It resonated with Tee, and she displayed the quote prominently above her front door.

When Tee moved to San Francisco in the early 1970s, she came out as a lesbian and soon used even more explicit sexual imagery by photographing women kissing and making love. Traditional art galleries refused to show her work, so Tee exhibited in alternative venues such as women's coffeehouses, bookstores, and lesbian bars—and the emerging feminist press frequently published her images.

In San Francisco, Tee began to work in sex education, joining the staff of the Sex Education Switchboard, an early telephone hotline offering a free public service that provided anonymous information about sex. From this experience, Tee became convinced of the need for accessible images of female genitalia. In November 1975, she published the Cunt Coloring Book, a collection of line drawings of vulvas said to be "one of the most emblematic and important activist artworks to come out of the women's movement." ${ }^{\prime 37}$

On a visit to friends in southern rural Oregon, Tee decided that country living suited her. In the early 1980s, she moved from San Francisco to Oregon, where dozens of lesbian communes and collectives had grown from the Backto-the-Land movement of the late 1960s and 1970s. Tee had inherited enough money to purchase a small house and property in Sunny Valley, in southern Oregon, where she lived simply and became a central figure in Oregon's lesbian community. From this base, Tee grew into a candid and forthright activist-artist, developing a national reputation by writing, exhibiting, and publishing in lesbian and feminist journals. ${ }^{38}$ One of her former partners, also a writer of popular lesbian fiction, said Tee "immortalized the linchpins of lesbian culture; she led us to understand that what we were doing was important, that we were important, that our work had value." 39

Between 1976 and 1988, Tee designed more than fifty book covers for the lesbian romance novels published by Naiad Press. Tee's Yantras of Womanlove, published in 1982, is a book of erotic photography meant to create positive and

${ }^{37}$ Jenni Sorkin, "Tee Corinne," WACK! Art and the Feminist Revolution (Cambridge, Mass.: The MIT Press, 2007), 226

${ }^{38}$ Sorkin, "Tee Corinne," 226.

${ }^{39}$ Lee Lynch, "Tee Corinne, 1943-2006" in Out in the Mountains, 10 October 1996, available at http:// www.mountainpridemedia.org/oitm/issues/2006/10oct2006/ae05_corinne.htm, accessed June 2007.

${ }^{40}$ Tee Corinne, "Lesbian Photography: A Personal and Public Exploration," unpublished essay, 1985, Tee Corinne Papers, Coll. 263, Special Collections and University Archives, University of Oregon. 
life-affirming images and negate the pop culture clichés of lesbians as adolescents or "predatory vampires." 40

Tee frequently used a technique called "solarization," which created a reverse/positive/negative image to produce a photograph that both hid and revealed; "the 'open-hidden-ness' of her photographs was also a metaphor for lesbian sexuality itself-invisible unless you know what to look for, and then, suddenly, it has been there all along." ${ }^{41}$ One such solarized photograph of two women making love was published on the cover of the lesbian periodical Sinister Wisdom and later reproduced as a poster. In the lesbian world it was considered "an immortal work of art, both lovely and iconic." 42

By the time I met Tee, in the late 1990s, she was firmly established as a pioneer of lesbian erotica and imagery with a national and even international reputation. I could hardly believe my good fortune when I realized that no other repository in the United States had laid claim to her personal papers and artwork. We talked about her papers, and Tee also helped me acquire the dozen Southern Oregon Lesbian Community collections now a part of the manuscript collections at the University of Oregon. She helped me reach out to women with papers that might become part of our collection. Building on the networks the lesbian communes had maintained for nearly thirty years, she invited me to gatherings at her home and gave me the opportunity to talk to the women about collecting and preserving their records. In fact, I frequently use her words to explain my project to collect the papers of lesbians in Oregon, "The lack of a publicly accessible history is a devastating form of oppression. Lesbians face it constantly." 43

Sometimes archivists and librarians have the good fortune to develop friendships with donors; over the course of a decade that is what happened with Tee and me. In a combined professional relationship and friendship, we were able to develop trust in each other. I believe this trust was core to Tee's desire to leave her entire estate to Special Collections and University Archives. She trusted me to do the right thing and knew that her gift would make a lasting impact on our efforts to preserve and make available the lesbian history of Oregon.

At the same time, it was important for me to acknowledge and remain aware that a personal friendship could potentially color a professional relationship. Even subconsciously, might I in some way give her collection preferential treatment? Or, would I find it hard to say no to a special request? Would it be difficult to refuse materials that I judged not pertinent or appropriate to

\footnotetext{
${ }^{41}$ Tamsin Wilton, "Corinne, Tee (1943-2006)," GLBTQEncyclopedia, available at http://www.glbtq.com/, accessed June 2007.

${ }^{42}$ Lynch, "Tee Corinne."

${ }^{43}$ Tee A. Corinne, "Lesbian Photography on the U.S. West Coast, 1972-1997," in Women Artists of the American West (1998), available at http://www.cla.purdue.edu/waaw/Corinne/, accessed June 2007.
} 
L I F E T I M E S A N D L E G A C I E S : M O R T A L I T Y , I M M O R T A L I T Y ,

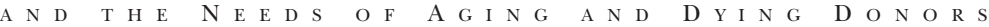

our collection development policies? By good luck and mutual respect, none of these issues arose between Tee and me, but an archivist must be on guard and attentive to them in the relationship balance with a donor.

In 2006, when Tee was diagnosed with cancer, I spoke to her several times about gathering up the remainder of her papers and personal library to add to her existing collection at the University of Oregon. These were difficult conversations for me. I had visited Tee's lover, Beverly Brown, shortly before her death in October 2005, but otherwise I had had little experience dealing with donors at the end of their lives. I was uncertain how to talk with Tee or broach the topic of her impending death, even though we were friends. When we spoke on the phone, we talked about practicalities, such as when I could drive to Sunny Valley (two-and-a-half hours south of the university in Eugene) to pick up more papers and photographs. Often I hesitated even to call her; email seemed better, less invasive. A friend created a blog so that Tee's friends far and wide could read updates about her health, treatment, and state of mind. I did not spend much time reading it since it made me feel like a vulture, and I was reluctant to read the testimonials and good wishes from friends. The blog did mention that telephone calls were difficult for Tee.

To be honest, I had not quite realized that Tee's cancer was terminal-it is hard to know exactly what is going on when the patient is deciding which treatment to take, and there is often so much uncertainty about the effectiveness of treatments. I guess I was in denial about the hard issue of Tee's impending death.

I had not realized that the archivist or manuscripts librarian plays a major role when a donor is dying, and I now understand I could have been much more open and forward with Tee. The experience taught me that the archivist is the keeper of someone's life, as the collector and manager of that person's papers. Tee's artwork and published writings will always represent her creativity, but a collection is more extensive and varied than a public body of creative work. It is the living and lasting representation of a life, and therefore the archivist is vitally important to the dying donor. When I did call, someone else always answered and warned me that Tee was not taking calls. But when Tee was told I was calling, she always rushed to talk with me. In a sense, I represented her legacy. She knew her legacy was important.

\section{Wills and Working with Library Development}

In one conversation, just a few weeks before she died, Tee said she was leaving her entire estate and her copyright to the University of Oregon. She wanted us to use the proceeds to process her collection and the many other 
lesbian collections we hold. This was welcome but complicated news, because the value of Tee's estate rested almost entirely in her house and property, six acres of beautiful land in Josephine County. In the end, the house and property sold for just over a quarter of a million dollars, a sizable endowment that will be used to process and make available the lesbian collections at the University of Oregon.

After our conversation about her bequest, I started to worry about the exact words Tee had used in her will. Did they express her desire to give her property to our department of Special Collections and University Archives, or did she just mention "The University of Oregon?” It made a difference, as I soon discovered in a frantic flurry of meetings with our library development officer.

My concern was well founded, because the text of the old will stated, "I give all of my artwork (including ... ) to the University of Oregon." In another section of the will, Tee stated that she was giving her estate to the University of Oregon. However, as I learned from our library development officer, this wording was too general. Unless we wanted the State of Oregon to take a direct hand in the bequest, we needed the text to say that the estate was donated to the University of Oregon Foundation, a private entity created to handle funds that support the university, and we needed to say that the proceeds would go to Special Collections and University Archives for the specific purpose of benefiting the collections of the southern Oregon lesbian community. A few days later, when I drove down to Tee's house to box up more material for the collection, Tee's executor, Jeanne Simington, was at the house, and I was able to discreetly ask her about the wording of the will. Jeanne was as eager as I was to get the wording right, and she immediately created a codicil to the will to update the wording and make it legal. We were able to guarantee that Tee's wishes would be fulfilled.

\section{Saying Goodbye to a Dying Donor}

Many archivists, particularly those who have worked in the profession for years, have had to say goodbye to dying donors. In Tee's case, I knew exactly when she was going to end her life. The week before, I drove down to Sunny Valley in a cargo van to pack up more of Tee's papers and photographs, as well as her extensive library of art books. No one else at the library was available to help me, so I made the trip on my own. It was a hot day in August, and after I arrived, I spent several hours packing heavy, oversize art books. Most archivists have removed heavy materials from shelves or file cabinets, put them in record storage boxes, loaded them into a truck, knowing those motions will be reversed at the library or archives. 
L I F E T I M E S A N D L E G A C I E S : M O R T A L I T Y , I M M O R T A L I T Y ,



When it came time to say my final goodbye to Tee, I was exhausted and uncomfortable, thinking I just wanted to get back to the library to unload the van. I dreaded it, and yet I knew it was my last chance to talk with her. I was worried that in my anxiety I would not find the right words, and I struggled to control my emotions and keep myself from crying. Saying goodbye was a final act, a closing of a friendship. Saying goodbye meant that I had to face the reality of her impending death. I knew from my previous experience with Tee's partner, Beverly Brown, just a year before, that when a person is very near death, she may not have the energy to comfort others; the dying person is often focused on her own pain and inner thoughts. I walked to the side of Tee's bed and kept it simple: I told her that she had had a major impact on my life; I thanked her for her gift to Special Collections; I told her that I would do everything I could to ensure her legacy by maintaining and promoting her collection; I told her that I loved her; and then I leaned over and kissed her forehead. I could tell she was in physical pain.

Tee did not say anything but she did smile slightly and I think she nodded. A look in her eyes haunts me. I had seen the same look in Bev Brown's eyes when I said goodbye to her: a look of desperation or resignation. A week later Tee died, saying that taking her own life was a reasonable and responsible thing to do.

Working with the Executor

After Tee's death I began working closely with Tee's executor, Jeanne Simington, a lovely woman who had been assigned the demanding task of selling Tee's belongings, fixing up her property, selling it, and dealing with the lawyers and bankers-essentially closing down Tee's estate and making sure the proceeds came to my repository. This was the first time I had worked closely with an executor. The experience was often endearing. I received daily email messages from Jeanne detailing what she was doing. I began to realize that she wanted to make sure I knew she was accountable to the University of Oregon. I read updates about the repairs and improvements to Tee's property: the plumber who repaired broken pipes over the weekend, the septic system that had to be pumped and inspected, the wood-burning stoves and fireplaces that passed inspection, even details about the sale of Tee's Haviland china. Piece by piece, Jeanne accounted for every penny owed to Special Collections and University Archives at the University of Oregon.

We also inherited Tee's computers, a real treasure because all her email was on her PC, and her many digital art photographs were on her Apple PowerBook. Unfortunately, I never thought to ask Tee about her passwords. We were lucky with her PC, because staff in our systems office were able to transfer its data to 
our library server. But the laptop was a bigger problem-until one day, that is, when I turned it upside down and discovered that Tee had thoughtfully written her password on the underside of the machine.

\section{Grief Counselor: HeIping Those Left Behind}

Tee's story is very much a human story. My attempts to deal with each stage of Tee's death and its aftermath were skills that I learned not so much by being an archivist but simply through life experiences. First I had to say goodbye to a dying donor and grieve the death of a friend; then I had to work with an executor as the representative of the beneficiary of a will. Next I became grief counselor to a woman who had been Tee's last lover.

I have learned that life is neither linear nor black-and-white with clearly defined borders. Still, it seems to me a tragic part of Tee's story that when her partner Beverly Brown was diagnosed with colon cancer, Tee was unable to accept her fate and remained in denial through many months of treatments, long after the inevitability of Bev's death became apparent. The sad upshot was that Tee and Bev separated, and Bev moved to Portland. Tee became involved with another woman she met at an annual fall gathering of women in southern Oregon. At first, it seemed this relationship might offer Tee a way to heal the ongoing pain of Bev's illness. But Tee and Bev reconciled and reaffirmed their love for one another three weeks before Bev died in October 2005. Tee channeled her grief into a series of art photographs, which became one of her most important works, Scars, Stoma, Ostomy Bag, Portacath: Picturing Cancer in Our Lives. After Bev's death, Tee's relationship with the other woman faded into the background. A few months later, Tee learned of her own cancer, and the relationship came to an end, as Tee's thoughts began to center on her own death, and she spent time designing gravestones for Bev and herself.

But the other woman was still in love with Tee. After Tee died, she wanted to tell everyone who would listen that she was the love of Tee's life. Tee's other friends believed that they knew differently and soon grew tired of hearing these claims. One place to look for evidence of the relationship was, of course, in Tee's manuscript collection.

One day when I was at our reference desk, a woman asked to speak to me. I immediately recognized Tee's last lover (ever the artist and amateur archivist, Tee had taken pictures of her). We went to my office and began a conversation, and I became an impromptu grief counselor. While this woman quietly sobbed, she asked me to give to her everything that she had written to Tee: letters, postcards, and any other documentation. She explained why she wanted them and insisted on the importance of her relationship with Tee, but I explained that I could not 
L I F E T I M E S A N D L E G A C I E S : M O R T A L I T Y , I M M O R T A L I T Y ,

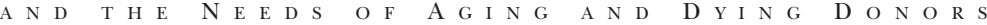

remove any documents from the collection; that in fact, if this woman wanted the world to know how strong her relationship with Tee was, well then, what better way than to leave those materials in the collection. She seemed comfortable with that solution, and I think she felt better having met me and talked to me. In nearly thirty years as an archivist, I had never before had such an experience.

\section{Conclusions and Suggestions}

Traumatic though it was, my work with Tee before and after her death taught me many lessons about working with aging and dying donors. Some are about practical matters; others about deeply personal human interactions. Some of the lessons I would like to emphasize are:

- Develop a good working relationship with your institution's development officer so you can get sound advice for future work with aging or dying donors.

- Think about specific wording in donors' wills and make sure the phrases work to your advantage and express the donors' wishes.

- Think about how to talk openly with aging or dying donors before the end is near.

- Dying donors want to talk about their legacy and how that legacy is represented in their collections. They do not necessarily want to talk about how you feel about their dying process, or how they are feeling about dying. Focused on dealing with their pain or impending death, they do not have the energy for extensive conversations.

- Finally, remember that forming friendships with dying donors is not for the faint of heart. The close personal relationship that Tee and I built helped ensure her legacy, but it also left me bereft at her loss-and humbled to realize how thin the line between professional objectivity and emotional subjectivity really is.

When I was in graduate school in archives administration so many years ago, dealing with aging or dying donors and helping to draft wills were not fully discussed. Although my story can offer only a personal example, my hope is that archives educators teach these topics and that new archivists are better prepared for these circumstances.

\section{S e I e c t B ibliography}

Ashenburg, Katherine. The Mourner's Dance: What We Do When People Die. New York: North Point Press, 2002. A survey of rites, rituals, and attitudes surrounding death in various cultures. 
Binstock, Robert, and Linda K. George, eds. Handbook of Aging and the Social Sciences. $6^{\text {th }}$ ed. Boston and London: AP Professional, 2005. A standard text with essays by experts in the field, plus extensive bibliographies.

Birren, James E., et al., eds. Handbook of the Psychology of Aging. $6^{\text {th }}$ ed. Amsterdam: Elsevier, 2007. A good compendium of essays by experts in the field, including an extensive bibliography of specialized works.

Callanan, Maggie, and Patricia Kelley. Final Gifts: Understanding the Special Awareness, Needs, and Communications of the Dying. New York: Poseiden Press, 1992. Includes numerous illustrative case histories.

Cole, Thomas R. The Journey of Life: A Cultural History of Aging in America. Cambridge and New York: Cambridge University Press, 1992. Worthwhile reading for understanding the diversity of attitudes toward aging in the United States.

Corless, Inge, Barbara B. Germino, and Mary A. Pittman, eds. A Challenge for the Living: Dying, Death, and Bereavement. London: Jones and Bartlett, 1995. A textbook anthology of readings, including good bibliographies. Published in the United Kingdom but relevant to the United States.

Dychtwald, Ken. Age Power: How the 21 $1^{\text {st }}$ Century Will Be Ruled by the New Old. New York: Jeremy P. Tarcher/Putnam, 1999. Although somewhat lacking in technical information, this book places age in the perspective of current social and technological trends.

Frieden, Betty. The Fountain of Age. New York: Simon and Schuster, 1993. A noted feminist explores ideas and perceptions behind aging.

Glaser, Barney G., and Anselm L. Strauss. Awareness of Dying. Chicago: Aldine Publishing Company, 1965. A standard textbook and a bit out of date, but provides good basic information.

Goodman, Lisa M. Death and the Creative Life: Conversations with Prominent Artists and Scientists. New York: Springer Publishing Co., 1981. Insights for relating to creative people at the ends of their lives.

Jecker, Nancy S., ed. Aging and Ethics: Philosophical Problems in Gerontology. Totowa, N.J.: Humana Press, 1992. This collection of essays on all aspects of dying is like a textbook and contains much practical advice.

Johnson, Peggy. "Grace Under Pressure: Relations with Library Donors." Technicalities 13 (August 1993): 5-7. Useful approaches to donors.

Kaiser, Barbara J. "Problems with Donors of Contemporary Collections." American Archivist 32, no. 2 (1969): 103-7. Valuable advice from a seasoned and perceptive archivist.

Kastenbaum, Robert. Our Way: The Final Passage through Life and Death. Berkeley and Los Angeles: University of California Press, 2004. A good cultural history of death and dying in a variety of periods and cultures, from ancient times to the present. 
L I F E T I M E S A N D L E G A C I E S : M O R T A L I T Y , I M M O R T A L I T Y ,

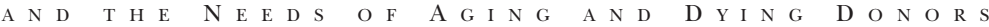

Kessler, David. The Needs of the Dying: A Guide for Bringing Hope, Comfort, and Love to Life's Final Chapter. New York: Harper, 2007. Good practical advice from a noted expert in the field.

Kübler-Ross, Elisabeth. On Death and Dying. New York: Macmillan, 1969. A classic and groundbreaking text on the subject. Although many have criticized this work, it is still worth reading as a starting point in research on dying.

Kübler-Ross, Elisabeth, and David Kessler. Life Lessons: Two Experts on Death and Dying Teach Us about the Mysteries of Life and Living. New York: Touchstone, 2000. More of a self-help book for the dying and infirm, but also provides good insight for caregivers and others.

- On Grief and Grieving: Finding the Meaning of Grief through the Five Stages of Loss. New York, London, Toronto, Sydney: Scribner, 2005. Further refinement of the original Kübler-Ross work.

Kuhl, David. What Dying People Want: Practical Wisdom for the End of Life. New York: Public Affairs, 2002. Focuses on the dying person and her or his needs, but good practical information for caregivers as well.

Lesy, Michael. The Forbidden Zone. New York: Anchor Books, 1987. An imaginative and highly insightful study of people directly involved with death, from an innovative historian and the author of Wisconsin Death Trip, among other photographic essays. This book contains graphic and potentially disturbing narratives.

Lustbader, Wendy. Taking Care of Aging Family Members: A Practical Guide. New York: The Free Press, 1986. Focused on family members, but also insightful for caregivers and others.

Moody, Harry R. Ethics in an Aging Society. Baltimore : Johns Hopkins University Press, 1992.

Stevens, Michael E. "Voices from Vietnam: Building a Collection from a Controversial War.” American Archivist 64 (Spring/Summer 2001): 115-20. A good case study in collecting papers from survivors.

Stewart, Virginia R. "A Primer on Manuscript Field Work." A Modern Archives Reader: Basic Readings on Archival Theory and Practice. Washington, D.C.: National Archives and Records Service, 1984, 124-38. Basic information on donor relations, although not specifically focused on aging or dying donors.

Tirrito, Terry. Aging and the New Millennium: A Global View. Columbia: University of South Carolina Press, 2003. A good textbook overview of the subject.

Williams, Mark E. The American Geriatrics Society's Complete Guide to Aging and Health. New York: Harmony Books, 1995. An encyclopedia of aging, with information on all aspects of the subject. 